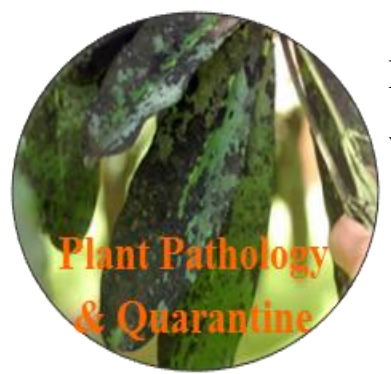

\title{
Morphological and molecular identification of Fusarium oxysporum f. sp. lycopersici associated with Olea europaea var. sylvestris decline phenomenon in Tunisia
}

\author{
Hlaiem $S^{1,2^{*}}$, Della Rocca $G^{3}$, Barberini $S^{3}$, Danti $R^{3}$ and Ben Jamâa $M^{1}$ \\ ${ }^{1}$ University of Carthage, National Institute for Research in Rural Engineering Water and Forest (INRGREF), LR11 \\ INRGREF01 Laboratory of Management and Valorization of Forest Resources, Bp. 10, 2080, Ariana, Tunisia \\ ${ }^{2}$ University of Carthage, National Agronomic Institute of Tunisia (INAT), Department of Phytiatry, 43 street Charles \\ Nicolle, 1082, Tunis Mahrajene, Tunisia \\ ${ }^{3}$ National Research Council, Institute for Sustainable Plant Protection of Italy (IPSP-CNR), Unit of Plant Protection, \\ Via Madonna del Piano10, 50019, Sesto Fiorentino, Firenze (Florence), Italy
}

Hlaiem S, Della Rocca G, Barberini S, Danti R, Ben Jamâa ML 2021 - Morphological and molecular identification of Fusarium oxysporum f. sp. lycopersici associated with Olea europaea var. sylvestris decline phenomenon in Tunisia. Plant Pathology \& Quarantine 11(1), 15-22, Doi 10.5943/ppq/11/1/3

\begin{abstract}
Decline phenomena and mortality of Olea europaea var. sylvestris (oleaster) have been reported throughout the forest of Henchir Kort (northeastern of Tunisia). The affected plants show progressive dieback of shoots, twig blight symptoms and trunk canker. The fungi appear to have the most significant potential threat to the disease. However, it has been less well-studied in Tunisia. A survey on the causal agents of $O$. europeae decline attacked twigs with symptoms of wilting and vascular necrosis were collected. The causal agent of the syndrome was identified as Fusarium oxysporum f. sp. lycopersici based on morphological characteristics and molecular identification performed by sequencing the ITS region of the ribosomal DNA. Fusarium species are among the most aggressive telluric fungi, causing diebacks of many plant species, especially on Olea europaea. To the best of our knowledge, this is the first record on the occurrence of Fusarium oxysporum f. sp. lycopersici on O. europaea in the word and in Tunisia.
\end{abstract}

Keywords - Dieback - Fungi - Identification - ITS region

\section{Introduction}

The olive tree is present on six continents: Europe, North America, South America, Africa, Asia and Oceania. It's a very ancient Mediterranean species. It belongs to the family of Oleaceae, genus Olea, species europaea. Two subspecies distinguish it: Olea europaea var. sylvestris (oleaster) and Olea europaea var. sativa (cultivated olive tree) (Villa 2003). Its wild form Olea europaea var. sylvestris is mainly found in Mediterranean countries: Portugal, Spain, Italy, Turkey, Greece, Morocco, Syria and Tunisia (Villa 2003). Furthermore, O. europaea var. sylvestris seems to be the ancestor of the cultivated olive tree (Belaj et al. 2010). The economic and ecological interest of the oleaster is major. It is used as a firewall to maintain soils and limit erosion (Breton et al. 2006). 
However, this evergreen specie is withering in countries of the Mediterranean basin, including Tunisia (Lazzizera et al. 2008, Moral et al. 2009), due to the interaction of several abiotic factors (anthropic action, drought, water stress, and fires), and biotics (insect pests and pathogenic fungi) (Ben Jamâa \& Hasnaoui 1996). Most fungal species causing dieback of oleaster are common saprophytes or secondary invaders usually penetrating through injuries made by biotic or abiotic factors (Lazzizera et al. 2008). Moreover, infections caused by fungi can cause very worrying diebacks, such as those caused by telluric fungi including Fusarium spp. which have been shown to cause symptoms of wilting and partial or total dieback of the olive (Jardak et al. 2007, Trabelsi et al. 2017) and caused extensive damage in several countries in the Mediterranean basin (PorrasSoriano et al. 2003). The Fusarium genus is one of the most complex and adaptive species in the Nectriaceae. The Fusarium oxysporum (Fo) species complex includes plant, animal and human pathogens and a diverse range of non-pathogens (Gordon 2017). This fungal pathogen is widely represented with a predominance of Fusarium oxysporum (Chliyeh et al. 2017), which are responsible for two distinct types of symptoms: wilting of the aerial part of the plant and root and/or collar rots (Gordon 1965). Members of Fusarium species are ubiquitous soil-borne pathogens of a wide range of horticultural and food crops which cause destructive vascular wilts, rots, and damping-off diseases (Bodah 2017). In particularly, Fusarium oxysporum f. sp. lycopersici first described in Europe at the end of the 19th century; it is present in dozens of countries on every continent (Blancard et al. 2009). Based on its economic importance and scientific interest, this species has been ranked among the "top 10" of plant pathogenic fungi (Dean et al. 2012).

In this context, this work consists of (i) the isolation of the pathogen (Fusarium) from symptomatic oleaster branches, (ii) its morphological identification (macroscopic and microscopic) and (iii) its molecular identification.

\section{Materials \& Methods}

\section{Study area}

The study was carried out in 2017, in the forest of Henchir Kort (36.30'.406" N; 10.38'.780"E) in Cap-Bon in the northeastern of Tunisia (Fig. 1). The vegetation is a mixture of pine trees with Mediterranean scrub composed mainly of Olea europaea var. sylvestris.

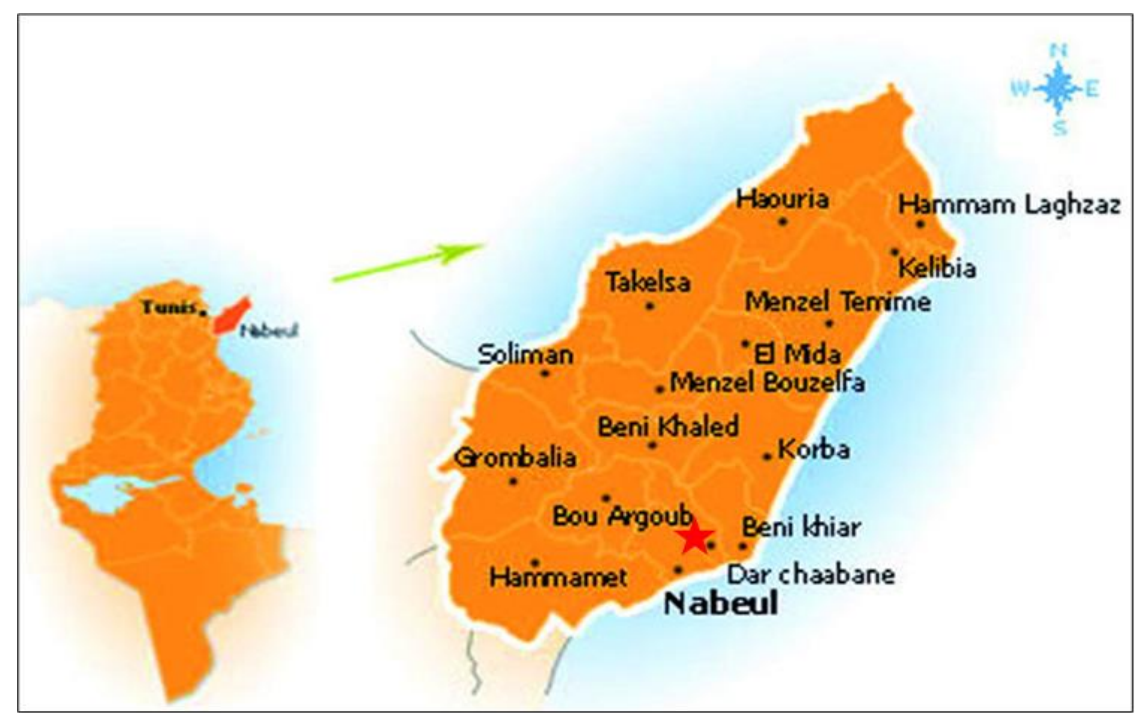

Fig. 1 - Localization of studied site (Henchira Kort forest is indicated with a red star).

\section{Phytosanitary status}

Damage degree was estimated based on visual appreciation of disease symptoms and a decline class of each $O$. europaea plant was assessed following the methodology described by 
Franceschini et al. (2005), with: (C0) no attack /absence of symptoms; $(\mathrm{C} 1)=1$ to $25 \%$; $(\mathrm{C} 2)=26$ to $50 \% ;(\mathrm{C} 3)=51$ to $75 \%$ and $(\mathrm{C} 4)=76$ to $100 \%$.

\section{Collection of samples and isolation}

In December 2017, typical disease symptoms were collected from stems of O. europaea and transferred to the laboratory. First, all samples are superficially disinfected using the surface sterilization method described by Alves et al. (2013). Small pieces of necrotic tissue $(3 \times 3 \mathrm{~mm})$ were taken from the margin of infected tissues were placed in Petri dishes containing potato dextrose agar (PDA) added with streptomycin sulfate $(0.05 \mathrm{~g} / \mathrm{l})$ antibiotic according to the technique used by Franceshini et al. (2005) and incubated in the dark at $25^{\circ} \mathrm{C}$ for 3 days. Pure cultures were obtained by plating a small piece of mycelium from the margin of each colony grown on PDA and incubating them under the same conditions described above.

\section{Morphological and molecular identification}

Fusarium oxysporum was identified based on its cultural traits, conidial morphological characteristics by referring to identification keys (Rayner 1970) and forest mycology guide (Lanier et al. 1976). Colony morphology, including color, shape, and growth rate, was determined after 7 days of incubation on PDA at $25^{\circ} \mathrm{C}$ in darkness. Microscopic characters were studied according to the technique explained by Arzanlou et al. (2007). Dimension of microscopic structures were calculated based on 30 measurements for conidia morphology (shape, color, and cell number), size (length and width). The percentage of isolation frequency (IF) was calculated using the formula of IF (\%) Franceschini et al. (2005): IF = Ni/Nt x 100 with Ni (number of fragments colonized by the fungus) and $\mathrm{Nt}$ (total number of plated fragments).

Regarding the molecular identification, fungal DNA was directly extracted from mycelia growing on plates, using a commercial Kit Macherey-Nagel- 07/2014, Rev.09.PCR reactions were carried out with ITS1 and ITS4 primers (White et al. 1990) to amplify the ITS region of the ribosomal RNA as described by Alves et al. (2004). Products from PCR reactions were electrophoresed on a $1.5 \%$ agarose gel, then stained with GelRed, and visualized with UV transilluminator. The size of PCR products was estimated by comparison with a DNA ladder 100 bp plus, Transgen Biotech. All PCR amplifiers were sent for sequencing to the Interdepartmental Center for Chemical and Industrial Agricultural Biotechnology Services (Italy) laboratory. The representative sequence was deposed in GenBank.

\section{Phylogenetic analysis}

ITS sequences were used to conduct a phylogenetic analysis. Sequences of Fusarium species were retrieved from GenBank and aligned with sequence of the isolate (TN.24) obtained in this study. Sequences were aligned with ClustalX v. 1.83 (Thompson et al. 1997), using alignment parameters according to Linaldeddu et al. (2015). Phylogenetic tree was generated under Maximum Likelihood (ML) and analyzed to build the tree topology by the Neighbour-Joining method using MEGA 6.0 software (Tamura et al. 2013).

\section{Results}

\section{Incidence}

The Henchir kort forest investigation revealed that $40 \%$ of the examined oleaster plants showed dead twigs with necrotic lesions (Fig. 2). Subjects of decline class (C1) dominate with a rate of $50 \%$ followed by $(\mathrm{C} 2)$ subjects with a rate of $34 \%$ and $16 \%$ for (C3).

\section{Morphological characteristic}

Morphological identification was based on an observation combining colony morphology and microscopic spore observation; it was taken place after 7 days of incubation. A collection of 20 
isolates was obtained from infected samples collected from the oleaster plants at the Henchir kort forest. Preliminary identification of the genus was carried out by analyzing morphological traits based on the general appearance of colonies and the aspect of conidia. On PDA, colonies have a whitish, cottony and dense medium-growing mycelium (Fig. 3). Microscopic observation revealed the presence of very short conidiophore even invisible, septate macroconidia (3 to 7 septate) more or less curved fusiform measuring 2.9 to $4.9 \mu \mathrm{m}$ by 23 to $53 \mu \mathrm{m}$. The apical cell is tapered and curved, and the basal cell is pedicelled. Microconidia are ellipsoidal and slightly curved, measuring 2 to $3.5 \mu \mathrm{m}$ by 4.5 to $11 \mu \mathrm{m}$ (Fig. 2).

In this study, Fusarium species were isolated from all sampled O. europaea plants showing disease symptoms and $45 \%$ of isolates were identical to Fusarium oxysporum f. sp. lycopersici.

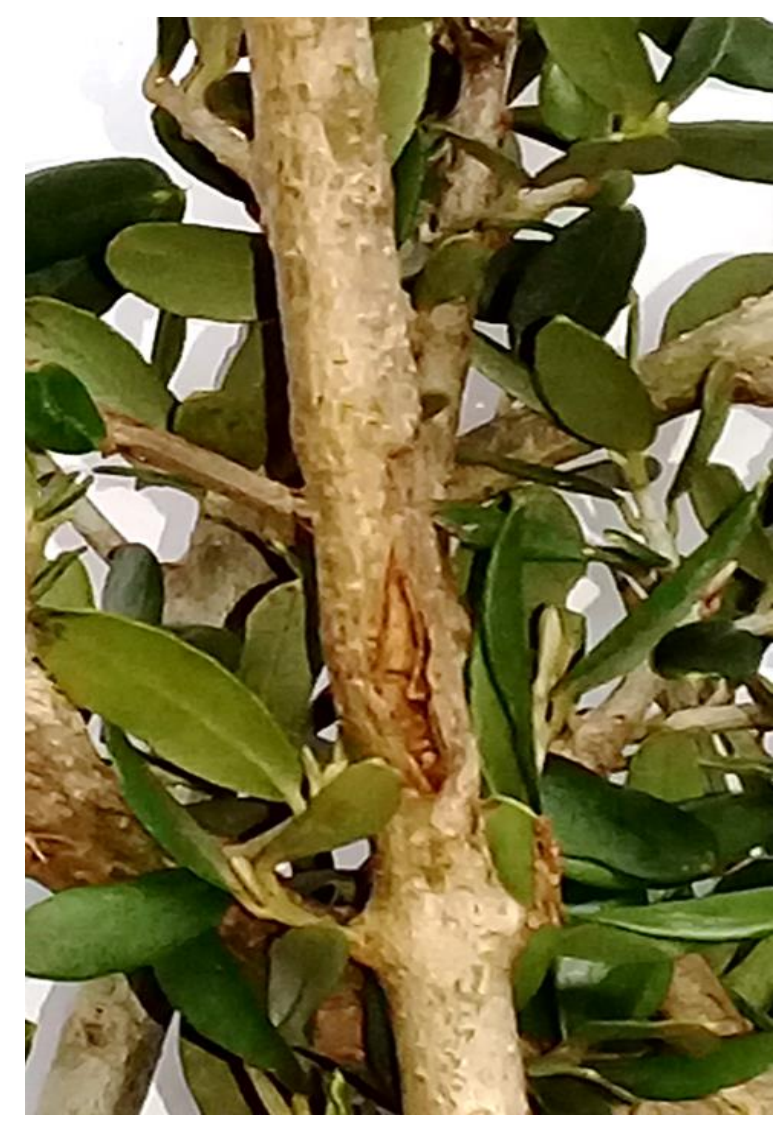

Fig. 2 - Necrotic lesion on stem observed in naturally infected Olea europeae plant.
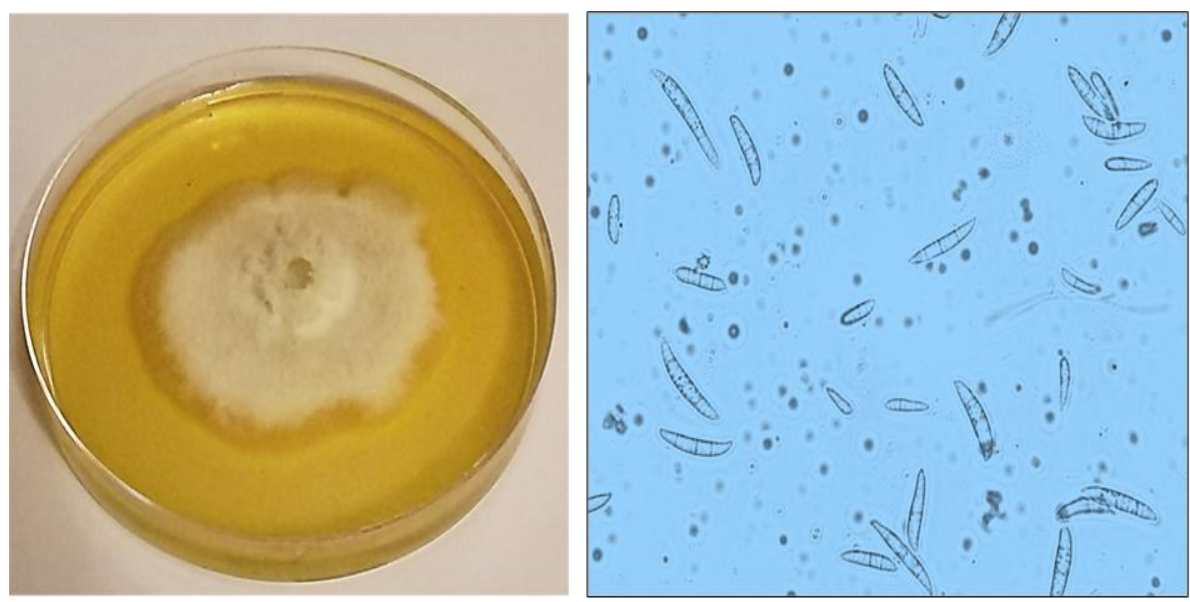

Fig. 3 - Fusarium oxysporum f. sp. lycopersici: Macroscopic appearance of the colony incubated on PDA at $25^{\circ} \mathrm{C}$ for 5 days (right) and microscopic appearance of conidia (40X) (left). 


\section{Phylogenetic analyses}

A representative isolate was selected for molecular identification and the identity of the species was confirmed by DNA sequence analysis of the ITS regions. The BLAST research of the isolate TN.24 selected for molecular identification showed 98\% homology with Fusarium oxysporum f. sp. lycopersici (FSOT) (KY100124) and the representative sequence was deposited in GenBank under the accession number (MN843963). The phylogenetic tree, resulting from the PCR amplification sequence of the ADNr nuclear operon using the ITS1 and ITS4 primers of the isolate TN.24 obtained in this study reveals that our isolate is grouped with other $F$. oxysporum $\mathrm{f}$. sp. lycopersici (FOL) (Snyder \& Hansen 1940) downloaded from the GenBank database and separate from the group of F. equiseti (Fig. 4).
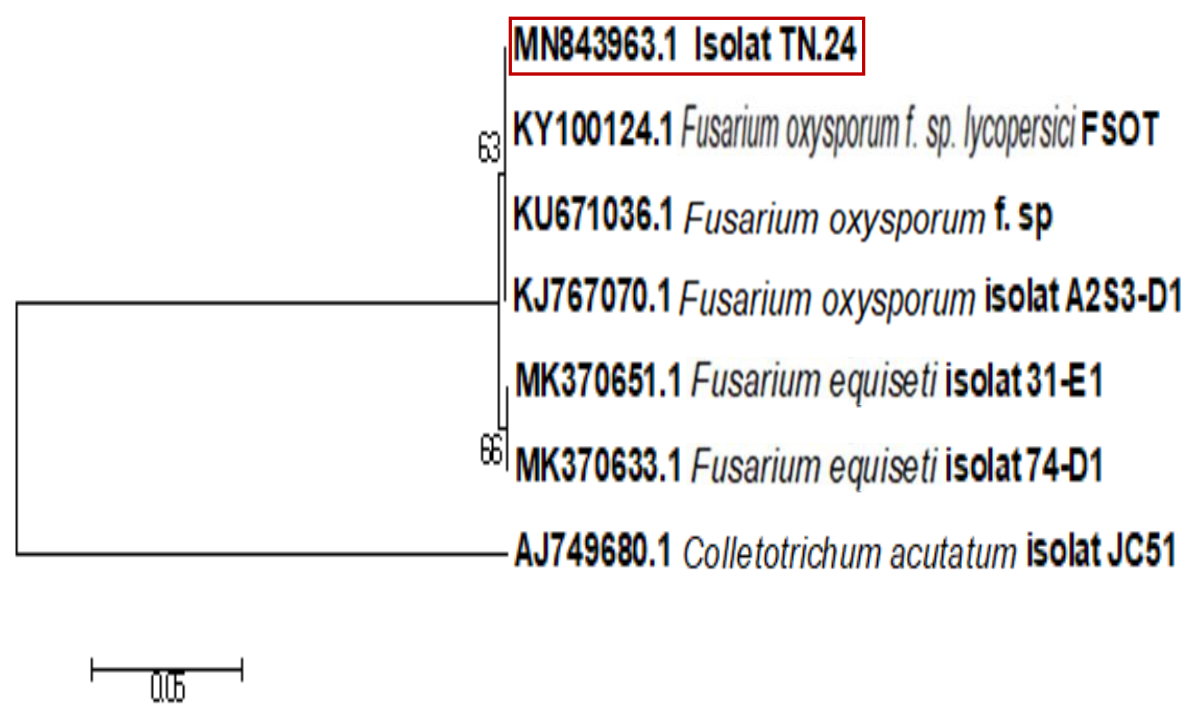

Fig. 4 - Phylogenetic tree obtained from ITS sequence data from the TN.24 isolate. Bootstrap support values (\%) from 1000 replications are shown at the nodes. The tree is rooted in Colletotrichum acutatum. The scale bar shows 0.005 substitutions per site.

\section{Discussion}

Surveys in the Henchir Kort forest revealed the presence of dieback and necrosis on the twigs of olive shrubs resulting in defoliation and drying of new shoots. The pathogen was isolated from samples of the infected branches. Based on macroscopic and microscopic morphological criteria, the isolate TN.24 obtained in this study was identified as Fusarium sp. which is consistent with the results obtained by Isebaert et al. (2005). Moreover, the amplification of ribosomal DNA by the two universal primers (ITS1/ITS4) made it possible to distinguish the exact isolated species. According, Nasraoui \& Lepoivre (2003) asserted that ITS regions are widely used for species identification. As a result, morphological and molecular phytopathological analyses have confirmed the presence of Fusarium oxysprum f. sp. lycopersici. Thus, O. europaea dieback is caused by this pathogen. The results obtained in this study are consistent with those of Cristobal-Alejo et al. (2016) in Mexico, which confirmed that Fusarium oxysporum f. sp. lycopersici (FSOT) caused significant damage to the stems of the Saccharum officinarum. Others researches, also such as those of Al-Ahmad (1984) in Syria and Sanchez et al. (1998) in Spain, have shown that telluric fungi causing threat to olive trees. In fact, the genus Fusarium includes many plant pathogenic species that can induce disease in many plants. Furthermore, symptoms of dieback caused by the genus Fusarium have been observed on young olive trees planted in Morocco (Chliyeh et al. 2014). As well, two species $F$. oxysporum and $F$. solani were isolated from crown and olive stems in Algeria (Merzoug et al. 2018). In Saudi Arabia, AL-Shebel et al. (2005) identified two olive dieback agents, Fusarium spp. et Verticillium dahliae. In the other hand, Messiaen \& Cassini (1968) confirmed that Fusarium oxysporum f. sp. radicis lycopersici attacks the root parts and 
Fusarium oxysporum f. sp. lycopersici (Sacc.) WC Snyder \& HN Hansen attacks the aerial parts of the plant. In addition, Asha et al. 2011 reported that Fusarium oxysporum f. sp. lycopersici (Sacc.) WC Snyder \& HN Hansen (FOL) caused vascular wilt of tomato disease and reduced the yield to the maximum extent.

\section{Conclusion}

This finding was the first record of Fusarium oxysporum f. sp. lycopersici as fungal pathogen associated with Olea europea var. sylvestris dieback in Tunisia. Despite the economic losses it causes, control of this pathogen is still limited to prophylactic measures, disinfection of the soil is never complete due to the difficulty of its production and to resistant strains (Benhamou et al. 1997). Therefore, and before the implementation of a strategy to control this phytopathogen, it is necessary to better understand the epidemiology and the mechanisms of fusarium oxysporum $\mathrm{f}$. sp. lycopersici infection to assess its aggressiveness by artificial inoculations on the branches of oleaster. The assessment of the pathogenicity of this pathogen is being appraised.

\section{References}

Al-Ahmad M. 1984 - Decline of olive trees in southern Syria. Arab J Plant Protection 2: 70-76.

Al-Shebel SM. 2005 - Studies on fungal olive disease in Al-Jouf and Riyadh Kingdom of Saudi Arabia, No. SP-8-46.

Alves A, Barradas C, Phillips AJL, Correia A. 2013 - Diversity of Botryosphaeriaceae species associated with conifers in Portugal. European Journal of Plant Pathology 135, 791-804.

Alves A, Correia A, Luque J, Phillips AJL. 2004 - Botryosphaeria corticola sp. nov. on Quercus species, with notes and description of Botryosphaeria stevensii and its anamorph Diplodia mutila. Mycologia 96: 598-613

Arzanlou M, Abeln ECA, Kema GHJ, Waalwijk C et al. 2007 - Molecular diagnostics for the Sigatoka disease complex of banana. Phytopathol. 97, 1112-1118.

Asha BB, Nayaka SC, Shankar ACU, Srinivas C, Niranjana SR. 2011 - Selection of effective bioantagonistic bacteria for biological control of tomato wilt caused by Fusarium oxysporum $\mathrm{f} \mathrm{Sp}$. Lycopersici. Bioscan Int quart. J. Life Sci. 6, 239-244.

Belaj A, Mounoz-Deiz C, Baldoni L, Satovic Z, Barranco D. 2010 - Genetic, diversity and relationships of wild and cultivated olives at regional level in Spain. Sci. Hortic 124, 323$330 \mathrm{p}$.

Ben Jamâa ML, Hasnaoui B. 1996 - Le dépérissement du chêne-liège (Quercus suber L.) en Tunisie Premières réflexions. Colloque National sur le dépérissement des Forêts au Maroc. CNRF Rabat-Maroc 28 et 29 Février, 10p.

Benhamou N, Rey P, Cherif M, Hockenhull J, Tirilly Y. 1997 - Treatment with the mycoparasite Pythiumolig and rum triggers induction of defence-related reactions in tomato roots when challenged with Fusarium oxysporum f. sp. radices - lycopersici. Phytopathology 87, p. 108121.

Blancard D, Laterrot H, Marchoux G, Candresse T. 2009 - Les maladies de la tomate : identifier, connaitre, maîtriser. Edition Quae C/O INRA, Versailles, 679 p.

Bodah ET. 2017 - Root Rot Diseases in Plants: A Review of Common Causal Agents and Management Strategies. Agricultural Research and technology 5 (3), 555661.

Breton C, Médail F, Pinatel C, Bervillé A. 2006 - De l'olivier à l'oléastre : origine et domestication de l'Olea europaea L. dans le Bassin méditerranéen. Cahiers Agricultures vol. 15, n 4.

Cristobal-Alejo J, Candelero De La Cruz J, Moo Koh FA, Rangel-Ortega A, Flores-Revilla C. 2016 - Estacion Nacional de Cuarentena de la Cana de Azucar, Centro de Investigacion y Desarrollo de la Cana de Azucar, a. C, Calle Rio Niagara Numero Exterior 111-1 Colonia Cuauhtemoc, Mexico, Ciudad de Mexico 06500, Mexico. 
Chliyeh M, Msairi S, Ouazzani-Touhami A, Benkirane R, Douira A. 2017 - Detection of Fusarium solani as a Pathogen Causing Root Rot and Wilt Diseases of Young Olive Trees in Morocco Annual Research \& Review in Biology, 13(5), 1-7

Chliyeh M, Rhimini Y, Selmaoui K, Ouazzani-Touhami A et al. 2014 - Survey of the fungal species associated to olive tree (Olea europaea L.) in Morocco. International Journal of Recent Biotechnology 2(2), 15-32.

Dean R, Van Kan JAL, Pretorius ZA, Hammond-Kosack KE. 2012 - The Top 10 fungal pathogens in molecular plant pathology. Mol. Plant Pathol. 13, 414-430.

Franceschini A, Linaldeddu BT, Marras F. 2005 - Occurrence and distribution of fungal endophytes in declining cork oak forests in Sardinia (Italy). IOBC/WPRS Bull. 28: 67-74

Gordon TR. 2017 - Fusarium oxysporum and the Fusarium Wilt Syndrome. Annual Review of Phytopathology 55, 23-39.

Gordon W. 1965 - Pathogenic strains of Fusarium oxysporum. Can. J. Bot 43, 1309-1318.

Isebaert S, Haesaert G, Devreese R, Maene P et al. 2005 - Fusarium spp and Fusarium mycotoxins in maize: a problem for Flanders. Commun. Agric. Appl. Biol. Sci 70, 129-136.

Jardak T, Jerraya A, Mahjoub M. 2007 - La protection intégrée de l'oléiculture dans les pays de l'Afrique de Nord. Organisation des Nations Unies pour l'Alimentation et l'Agriculture. Bureau sous régional pour l'Afrique du Nord. SNEA-Tunis, FAO. 2004.

Lanier L, Joly P, Bondoux PB, Ellemére A. 1976 - Mycologie et Pathologie Forestières. II. Pathologie Forestière. Masson Editeur, Paris.

Lazzizera C, Frisullo S, Alves A, Phillips AJL. 2008 - Morphology, phylogeny and pathogenicity of Botryosphaeria and Neofusicoccum species associated with drupe rot of olives in southern Italy. Plant Pathology 57, 948-956

Linaldeddu BT, Scanu B, Seddaiu S, Deidda A et al. 2015 - A new disease of Erica arborea in Italy caused by Neofusicoccum luteum. Phytopathologia Mediterranea 54, 124-127

Messiaen CM, Cassini R. 1968 - Recherches sur les Fusarium, La systématique des Fusarium, tome 19, p. 396-454.

Merzoug A, Taleb M, Sahla A. 2018 - Identification des principaux agent fongiques responsables du deperissement vasculaire et pourriture racinaire des oliviers dans le Nord-ouest Algérien. Revue Agrobiologia 8(2), 1117-1124

Moral J, Oliveira R, Trapero A. 2009 - Elucidation of the disease cycle of olive anthracnose caused by Colletotrichum acutatum. Phytopathology 99, 548-556

Nasraoui B, Lepoivre P. 2003 - Les champignons phytopathogènes, [Pathogenic fungi]. Pages 111-143, In Phytopathologie [Phytopathology]. Ouvrage collectif sous la direction de P. Lepoivre. De Boeck Université Eds., 427 p, Belgium.

Porras-Soriano A, Soriano-Martin ML, Porras-Pieddra A. 2003 - Grafting olive cv. ornicabra on rootstocks tolerant to Verticillium dahliae reduces their susceptibility. Crop Protection 22, 369-374.

Rayner RW. 1970 - A mycological color chart. CMI and British Mycology Society, Surrey, UK, $34 \mathrm{pp}$.

Snyder W, Hansen H. 1940 - The Species Concept in Fusarium. American Journal of Botany, 27(2), 64-67. Doi 10.2307/2436688

Sanchez-Hernandez ME, Ruiz DA, Perez de Algaba A, Blanco-Lopez MA, Trapero-Casas A. 1998 - Occurrence and etiology of death of young olive trees in southern Spain. European Journal of Plant Pathology 104, 347-357.

Tamura K, Stecher G, Peterson D, Filipski A, Kumar S. 2013 - MEGA6: molecular evolutionary genetics analysis version 6.0. Mol Biol Evol. 30(12): 2725-2729.

Thompson JD, Gibson TJ, Plewniak F, Jeanmougin F, Higgins DG. 1997 - The ClustalX windows interface: flexible strategies for multiple sequence alignment aided by quality analysis tools. Nucl Acid Res. 25(24): 4876-4882 
Trabelsi R, Sellami H, Gharbi Y, Krid S et al. 2017 - Morphological and molecular characterization of Fusarium spp. associated with olive trees dieback in Tunisia. 3 Biotech, 7: 28.

Villa P. 2003 - La culture de l'olivier. DE. Vitthi. 95p.

White TJ, Bruns T, Lee S, Taylor J. 1990 - Amplification and direct sequencing of fungal ribosomal RNA genes for phylogenetics. In Innis MA, Gelfand DH, Sninsky JJ, White TJ, eds. PCR protocols. A guide to methods and applications. San Diego (CA). Academic Press; p. 315-322. 